\title{
Pengaruh Kepemimpinan Kepala Sekolah Terhadap Motivasi Kerja Guru se Kecamatan Modoinding di Masa Pandemi Covid 19
}

\author{
Sarah Tombokan a, ${ }^{\text {a*}}$, Margareta O. Sumilat \\ ${ }^{\text {a }}$ Universitas Negeri Manado, Program Studi PGSD, Tomohon dan Indonesia \\ ${ }^{\mathrm{b}}$ Universitas Negeri Manado, Program Studi PGSD, Tomohon dan Indonesia \\ ${ }^{1}$ sarahtombokan@unima.ac.id*; margaretasumilat.@unima. ac.id
}

\begin{tabular}{ll}
\hline \multicolumn{2}{l}{ Informasi artikel } \\
\hline Sejarah artikel: & \\
Diterima & $: 08$ Mei 2021 \\
Revisi & $: 08$ Mei 2021 \\
Dipublikasikan & $: 06$ Juni 2021 \\
\hline
\end{tabular}

Kata kunci:

Motivasi,

Guru,

Kepala Sekolah

\begin{abstract}
ABSTRAK
Tujuan dari penelitian ini adalah untuk mengetahui Pengaruh Kepemimpinan Kepala Sekolah Terhadap Motivasi Kerja Guru guru SD se Kecamatan Modoinding serta untuk mnegetahui seberapa besar pengaruh. Hasil penelitian yang dilakukan menunjukan bahwa Berdasarkan hasil perhitungan uji signifikansi dan uji linearitas regresi di atas, dapat disimpulkan bahwa pengaruh Kepemimpinan Kepala Sekolah(X) terhadap variabel Motivasi Kerja Guru (Y) signifikan dan linier. Hal ini dibuktikan karena Fhitung $7.913>\alpha(0,05)$. Selanjutnya, persamaan regresi $\hat{Y}=37.299+0.297 \mathrm{X}$ menunjukan bahwa setiap kenaikan satu skor Kepemimpinan Kepala Sekolah akan menyebabkan kenaikan skor Motivasi Kerja Guru sebesar 0,297 pada konstanta 37.299. Berdasarkan table di atas diketahui bahwa besar Kepemimpinan Kepala Sekolah terhadap Motivasi Kerja Guru se Kecamatan Modoinding dapat adalah 0,150 atau 15 persen. Hal ini meneujukan bahwa $15 \%$ Kepemimpinan Kepala Sekolah menentukan Motivasi Kerja Guru se Kecamatan Modoinding. Sedangkan 85\% dipengaruhi oleh faktor lain yang tidak diteliti. Berdasarkan pembahasan di atas dapat disimpulkan bahwa Motivasi kerja guru-guru se Kecamatan Modoinding yang sedang tersebut hanya $15 \%$ datang dari pihak kepala sekolah mereka. Namun demikian bahwa kepala sekolah memiliki peran yang penting dalam mendorong motivasi guru dalam melaksanakan tugas mereka untuk mengajar. Semakin Kepala sekolah se Kecamatan Modoinding melaksanakan fungsinya secara maksimal sebagai manejer sekolah di masa pandemic Covid19, maka akan meningkatkan motivasi kerja guru,
\end{abstract} dimana kenaikannya bersifat linier.

\section{Keywords:}

Motivation,

Teacher,

Principal

\section{ABSTRACT}

The Influence of Principal Leadership on Teacher Work Motivation in Modoinding District during the Covid 19 Pandemic. The purpose of this study was to determine the effect of the principal's leadership on the work motivation of elementary school teachers in Modoinding district and to find out how much influence it had. The results of the research conducted show that based on the results of the calculation of the significance test and the linearity regression test above, it can be concluded that the influence of the Principal's Leadership (X) on the Teacher Work Motivation variable (Y) is significant and linear. This is evidenced because Fcount 7.913> $\alpha(0.05)$. Furthermore, the regression equation $\hat{\mathrm{Y}}=37.299+0.297 \mathrm{X}$ shows that every one increase in the Principal Leadership score will cause an increase in the Teacher Work Motivation score of 0.297 at a constant of 37.299.

Based on the table above, it is known that the amount of Principal Leadership on Teacher Work Motivation in Modoinding District can be 0.150 or 15 percent. This indicates that $15 \%$ of the Principal's Leadership determines the Work Motivation of Teachers in Modoinding District. 
Meanwhile, $85 \%$ is influenced by other factors not examined.The more principals in Modoinding District carry out their functions optimally as school managers during the Covid19 pandemic, the more teachers' work motivation will increase, where the increase is linear.

Copyright $(02021$ (Sarah Tombokan, Margareta O. Sumilat). All Right Reserved

\section{Pendahuluan}

Pada awal tahun 2020, seluruh rakyat Indonesia harus berhadapan dengan persitiwa yang belum pernah terjadi di Indoensia sejak Indonesia merdeka yaitu adanya virus yang mematikan, yaitu korona atau Covid-19. Sejak itu pula banyak hal telah berubah di negeri ini dan harus disikapi secara tepat dan cermat. Kebiasaan yang lalu kini harus kita tinggalkan dengan memasuki kebiasaan yang baru yaitu masa new normal. Kebiasan-kebiasaan baru telah muncul dalam kehidupan seluruh rakyat Indonesia bahkan dunia. Kebiasan-kebiasaan baru tersebut muncul dalam kehidupan umat manusia dalam segala aspek kehidupan termasuk sistem pendidikan di sekolah yang terkena dampak negatif dari meluasnya wabah virus korona. Para orang tua murid dan sekolah harus memeras otak agar anak anak sekolah tetap menjaga motivasi dan semangat belajarnya. Adanya pengeluhan-pengeluhan orang tua siswa terhadap aturan yang ditetapkan sekolah terhadap pembelajaran yang harsu dilaksanakan secara daring berdasrkan Surat Edaran (SE) Mendikbud Nomor 4 Tahun 2020 tentang Pelaksanaan Pendidikan Dalam Masa Darurat Coronavirus Disease (Covid-19). Salah satu pokok penting dalam edaran ini adalah keputusan pembatalan ujian nasional (UN) Tahun 2020.

Dalam keadaan ini, dituntut kepada seluruh elemen sekolah yaitu kepala sekolah dan guru untuk dapat memberikan inovasi dan kretifitas dalam melaksnakan tanggung jawabnya secara baik di masa pandemic Covid19 ini agar kegiatan belajar mengajar tetap berjalan dengan baik. Kepala sekolah sebagai manajer di sekolah harus mampu melaksanakan tugas sekolah dengan cara mempengaruhi parab guru untuk dapat melaksnakan tugasnya dengan baik.

Setiap organisasi pendidikan harus memiliki pemimpin pendidikan. Kepemimpinan secara sederhana adalah merupakan kemampuan yang dimiliki seseorang untuk mempengarui orang lain (Makawimbang, 2012:6). Kepala sekolah adalah pemimpin di sekolah. Dalam organisasi pendidikan, kepemimpinan pendidikan bertujuan mempengaruhi untuk menggerakkan pelaksana pendidikan dalam hal ini para guru dan tenaga kependidikan lainnya untuk melaksanakan tujuan pendidikan yang telah ditetapkan sebelumnya bias dicapai secara efektif dan efisien. Keberhasilan lembaga pendidikan salah satu factor penting adalah kepala sekolah Karena ia merupakan pemimpin di lembaganya, dan harus mampu membawa lembaganya untuk mencapai tujuan yang telah ditetapkan. Kepala sekolah menjalankan aktivitas manajerialnya berupa pengambilan keputusan pendidikan, keteladanan, komunikasi, motivasi dan pemberian pengarahan kepada guru yang akan ikut menentukan masa depan siswa di sekolah. Kepala harsu memiliki berkomitmen menghentikan penyebaran Covid-19, dan mendukung pemerintah mengubah sistem pendidikan yang pada mulanya proses pembelajaran dilakukan tatap muka di sekolah, diganti menjadi pembelajaran dari rumah.

Kepemimpinan secara sederhana adalah merupakan kemampuan yang dimiliki seseorang untuk mempengarui orang lain (Makawimbang, 2012:6). Kepala sekolah merupakan seorang pemimpin di sekolah. Dalam konteks organisasi pendidikan, kepemimpinan pendidikan diartikan sebagai proses mempengaruhi untuk menggerakkan pelaksana pendidikan sehingga tujuan pendidikan yang telah ditetapkan sebelumnya dapat tercapai secara efektif dan efisien.

Dalam upaya mencegah penularan virus korona di sekolah, maka menjadi tugas kepala sekolah untuk dapat mengoordinasikan kegiatannya kepada berbagai pihak, antara lain memberikan tugas kepada guru untuk melakukan kegiatan pembelajaran di rumah sesuai dengan mata pelajaran yang diajarkan melalui berbagai media online.

Di sisi lain, guru merupakan faktor yang sangat dominan dan paling penting dalam pendidikan formal pada umumnya karena bagi siswa guru sering dijadikan tokoh teladan bahkan menjadi tokoh identifikasi diri. Keberhasilan penyelenggaraan pendidikan sangat

42 | Jurnal Civic Educatioan: Media Kajian Pancasila dan Kewarganegaraan 
ditentukan dari kesiapan guru dalam mempersiapkan peserta didiknya melalui kegiatan belajar mengajar. Namun demikian prosisi strategis guru untuk meningkatkan mutu hasil pendidikan sangat dipengarhui oleh mutu kinerjanya. (Cindi G.S. dkk)

Agar memberikan dampak bagi siswa, salah satu syarat untuk mendapatkan hasil kinerja yang baik. Semakin tinggi nilai motivasi maka nilai kinerja pegawai akan semakin tinggi (Achmad Fadhil dan Yuniadi Mayowan 2018) dan Motivasi Kerja berpengaruh positif terhadap dan sgonifikan terhadap kinerja guru. (Riyadi dan Mulyapradana, 2017).

Kecamatan Modoinding Kabupaten Minahasa Selatan saat ini memiliki 17 Sekolah Dasar yang terdiri dari 9 sekolah milik pemerintah dan 8 sekoalh milik swasta. Juga melaksnakan system pembelajaran online. Berbagai hambatan juga muncul dalam pembelajaran on line misalnya:

Lemahnya jaringan internet, minimnya pengetahuan guru akan teknologi atau gaptek (gagap teknologi), kompetensi guru dalam menggunakan, keterbatasan akses teknologi seperti jaringan, dan fasilitas berupa laptop, komputer dan handphone, tidak semua guru siap mengoperasikan sistem pembelajaran daring dengan cepat, termasuk juga dalam guru mempersiapkan bahan pembelajaran secara digital. Masalah ini tentunya berdampak pada motivasi kerja guru-guru SD di Kecamatan modoinding dalam menjalankan tugas utamanya yaitu mendidik, mengajar, membimbing, mengarahkan, melatih, menilai, dan mengevaluasi peserta didiknya.

Berdasarkan latar belakang di atas, penliti tertarik untuk meneliti tentang kinerja guru sekolah dasar di masa pandemi (Studi di Kota Manado). Adapun rumusan maslah dirumuskan sebagai berikut:

1. Apakah Kepemimpinan Kepala Sekolah Berpengaruh Terhadap Motivasi Kerja Guru guru SD se Kecamatan Modoinding?

2. Seberapa besar pengaruh Kepemimpinan Kepala Sekolah terhadap motivasi kerja guru-guru

SD se Kecamatan Modoinding?

Dalam konteks lingkungan organisasi, kepemimpinan selalu melahirkan dua aspek, yaitu: kepemimpinan formal dan kepemimpinan informal. Kepemimpinan formal muncul apabila di lingkungan organisasi jabatan otoritas formal dalam organisasi tersebut diisi oleh orang-orang yang muncul dan berpengaruh terhadap orang lain karena kecakapan khusus atau berbagai sumber yang dimilikinya dirasakan mampu memecahkan persoalan organisasi serta memenuhi kebutuhan dari anggota organisasi yang bersangkutan.

(Syamsul 2017:276).

Menurut Syamsul Kepala sekolah yang efektif sedikitnya harus mengetahui, menyadari dan memahami tiga hal: (1) mengapa pendidikan yang berkualitas diperlukan di sekolah; (2) apa yang harus dilakukan untuk meningkatkan mutu dan produktivitas sekolah; dan (3) bagaimana mengelola sekolah secara efektif untuk mencapai prestasi yang tinggi. (Syamsul 2017:277).

Dalam rangka melakukan peran dan fungsinya sebagai manajer, kepalasekolah harus memiliki strategi yang tepat untuk mendayagunakan tenaga kependidikan melalui kerjasama atau koperatif, memberi kesempatan kepada para tenaga kependidikan untuk meningkatkan profesinya, dan mendorong keterlibatan seluruh tenaga kependidikan dalam berbagai kegiatan yang menunjang program sekolah.

Pertama, memberdayakan tenaga kependidikan melalui kerjasama atau koperatif dimaksudkan bahwa dalam peningkatan profesionalisme tenaga kependidikan di sekolah, kepala sekolah harus mementingkan kerjasama dengan tenaga kependidikan dan pihak lain yang terkait dalam melaksanakan setiap kegiatan. Kedua, memberi kesempatan kepada para tenaga kependidikan untuk meningkatkan profesinya, sebagai manajer, kepala sekolah harus meningkatkan profesi secara persuasif dan dari hati kehati. Ketiga, mendorong keterlibatan seluruh tenaga kependidikan, dimaksudkan bahwa kepala sekolah harus berusaha untuk mendorong keterlibatan semua tenaga kependidikan dalam setiap kegiatan di sekolah (partisipatif), dalam hal ini kepala sekolah bisa berpedoman pada asas tujuan, asas 
keunggulan, asas mupakat, asas kesatuan, asas persatuan, asas empirisme, asas keakraban, dan asas integritas.(Khairuddin:175)

Menurut Purwanto dalam Khairuddin (2020:176), bahwa seorang kepala sekolah mempunyai sepuluh macam peranan, yaitu : "Sebagai pelaksana, perencana, seorang ahli, mengawasi hubungan antara anggota-anggota, mewakili kelompok, bertindak sebagai pemberi ganjaran, bertindak sebagai wasit, pemegang tanggung jawab, sebagai seorang pencipta, dan sebagai seorang ayah.

Guna memutus mata rantai penularan virus corona di sekolah, maka tugas Kepala Sekolah harus bisa mengkoordinasikan kegiatannya kepada berbagai pihak, antara lain:

1. Memberikan surat tugas kepada guru untuk melakukan kegiatan pembelajaran di rumah sesuai dengan mata pelajaran yang diajarkan melalui berbagai media online.

2. Membuat surat edaran kepada orangtua mengenai pelaksanaan pembelajaran di rumah dalam rangka pencegahan penularan virus corona di sekolah.

3. Melakukan sosialisasi kepada siswa mengenai media pembelajaran secara daring dan tata cara penggunaan media tersebut.

4. Melakukan pengendalian dan pengawasan atas pelaksanaan pembelajaran di rumah yang telah ditugaskan kepada guru.

5. Melaporkan hasil kegiatan belajar kepada Dinas Pendidikan.(Khairuddin 2020.179)

Adapun motivasi penegrtian motivasi kerja Menurut Mangkunegara dalam Mirna Herawati dkk (2019:106) menjelaskan bahwa motivasi merupakan dorongan yang timbul pada diri seseorang yang menggerakannya untuk melakukan sesuatu. Sebagai bagaian dari organisasi Guru yang mempunyai motivasi kerja yang tinggi akan senantiasa bekerja keras untuk mengatasi segala jenis permasalahan yang dihadapi dalam proses kegiatan pembelajaran dengan harapan mencapai hasil yang lebih baik.

Menurut Uno (Mirna Herawati dkk 2019:106) Motivasi kerja merupakan salah satu faktor yang turut akan menentukan kinerja atau hasil kerja seseorang. Dalam bidang pendidikan motivasi kerja guru tidak lain adalah suatu proses yang dilakukan untuk menggerakkan guru agar perilaku mereka dapat diarahkan pada upaya-upaya nyata untuk mencapai tujuan yang telah ditetapkan. Dari uraian tersebut dan dengan merujuk pengertian motivasi, maka dalam penelitian ini yang dimaksud dengan motivasi kerja guru adalah dorongan yang ada di dalam diri seseorang guru untuk melakukan berbagai aktivitas guna mencapai suatu tujuan tertentu yang telah ditetapkan.

Menurut Komaruddin dalam Astrid Setianing Hartanti dan Tjutju Yuniarsih (22:2018) bahwa di dalam teori motivasi kerja terdapat tujuh indikator yang meliputi:

1. Semangat kerja,

2. Loyalitas kerja,

3. Perasaan bangga dengan tercapainya sasaran atau target,

4. Kebebasan menyampaikan pendapat dan gagasan,

5. Pengembangan potensi dan kemampuan,

6. Upah atau gaji,

7. Suasana kerja.

Dapat disimpulkan bahwa motivasi/ dorongan dalam bekerja dapat mempengaruhi semangat kerja guru dan menentukan kinerja yang akan dihasilkan oleh seorang guru.

\section{Metode}

dengan pendekatan kuantitatif. Subyek penelitian adalah guru-guru di SD Negeri se Kecamatan Modoinding sedangkan obyek penelitian adalah Kepemimpinan Kepala Sekolah dan Motivasi Kerja.

Penelitian survey dimaksudkan untuk memperoleh gambaran umum mengenai Kepemimpinan Kepala Sekolah dan Motivasi Kerja. Untuk menjelaskan variabel-variabel penelitian tersebut dilakukan dengan tingkat eksplanasi deskriptif dan korelatif. Tingkat eksplanasi deskriptif bertujuan menggambarkan hasil temuan variabel mandiri dari penelitian

44| Jurnal Civic Educatioan: Media Kajian Pancasila dan Kewarganegaraan 
mengenai kepemimpinan, Sedangkan tingkat eksplanasi korelatif dipergunakan untuk mencari hubungan antar variabel Kepemimpinan Kepala Sekolah dan Motivasi Kerja.

Populasi adalah wilayah generaliasi yang terdiri atas obyek/subyek yang mempunyai kualitas dan karakteristik tertentu yang di tetapkan oleh peneliti untuk dipelajari dan kemudian ditarik kesimpulannya (Sugiyono, 2013: 119).

Adapun populasi dalam penelitian ini adalah seluruh guru SD yang berada di Kacamatan Modoinding yang terdiri dari 75 guru.

Sampel adalah bagian dari jumlah dan karakteristik yang dimiliki oleh populasi tersebut. Bila populasi besar, dan peneliti tidak mungkin mempelajari semua yang ada pada populasi, misalnya karena keterbatasan dana, tenaga dan waktu, maka peneliti dapat menggunakan sampel yang diambil dari populasi itu. (Sugiyono, 2013: 120). Mengingat mengingat besarnya populasi dalam penelitian ini, maka peneliti mengambil sampel dengan menggunakan rumus slovin yaitu;

$$
n=\frac{N}{1+N e^{2}}(\text { Husein Umar 2013, hlm. 78) : }
$$

Keterangan

$n$ : jumlah sampel

$\mathrm{N}$ : jumlah populasi

e: batas toleransi kesalahan (error tolerance) $(10 \%)$

$$
n=\frac{75}{1+75 \times(0,1)^{2}}=\frac{75}{1,75}=43,18=43
$$

Adapun yang dilakukan dalam pengujian validitas instrumen meliputi uji validitas konstruk dan uji validitas empiris. Uji validitas konstruk bertujuan untuk mengetahui apakah butir-butir pernyataan pada instrumen sudah sesuai dengan konstruk teoritis atau belum. Validitas konstruk dapat diketahui dengan cara mengkonsultasikan instrumen kepada ahlinya, dalam hal ini adalah pembimbing. Uji validitas empiris dilakukan dengan cara menganalisis secara kuantitatif hasil uji coba instrument yang diseberkan kepada 30 responden (Sigiyono 2010;173). Pengujian validitas dengan cara melakukan korelasi antara skor item kuesioner dan total skor kuesioner berdasarkan rumus pearson.

Cara mengetahui butir pertanyaan dalam kuesioner yang disusun valid atau tidak adalah dengan membandingkan nilai $r_{\text {hitung }}$ dan $r_{\text {tabel }}$ atau Sig (2-tailed) dari masing-masing butir pertanyaan dengan taraf signifikansi $(\alpha=5 \%)$ pada $\mathrm{n}=30$ sebesar 0,361 . Jika nilai $r_{\text {hitung }}>$ $r_{\text {tabel }}$ atau Sig (2-tailed) lebih kecil dari taraf signifikansi $5 \%$, maka butir pertanyaan dalam kuesioner adalah valid.

.b. Uji Reliabilitas

Uji reliabilitas adalah keajegan atau konsistensi suatu hasil belajar, yaitu sejauh mana suatu tes dapat dipercaya untuk menghasilkan skor yang konsisten. Untuk mengetahui reliabilitas tes menggunakan rumus Alpha yaitu:

$$
r_{11}=\frac{k}{k-1}\left\{1-\frac{\sum s_{i}^{2}}{s_{t}^{2}}\right\}
$$

(Riduwan, 2007:116)

Dalam penelitian ini, analisis datanya menggunakan statistik parametric dimana, Validitas instrumen diuji dengan menggunakan koefisien korelasi antara skor butir soal dengan skor total $\left(r_{h}\right)$ melalui teknik korelasi product moment (pearson). Analisis dilakukan terhadap semua butir instrumen. Kriteria pengujian ditetapkan dengan cara membandingkan $r_{h}$ berdasarkan hasil perhitungan lebih besar dengan $r_{t}\left(r_{h}>r_{t}\right)$, maka instrumen dianggap valid. Sebaliknya jika $r_{h}$ lebih kecil dari $r_{t}\left(r_{h}<r_{t}\right)$, maka butir instrument dianggap tidak valid, sehingga tidak dapat digunakan untuk keperluan penelitian. 
Adapun hasil uji validitas instrumen dari dua variable penwelitian adalah:

Tabel:1

Uji Validitas Kepemimpinan Kepala Sekolah

\begin{tabular}{|ll|r|}
\hline & & $\begin{array}{r}\text { XTOTA } \\
\text { L }\end{array}$ \\
\hline X1 & Pearson Correlation & $.662^{* *}$ \\
& Sig. (2-tailed) & .000 \\
& $\mathrm{~N}$ & 30 \\
X2 & Pearson Correlation & $.697^{* *}$ \\
& Sig. (2-tailed) & .000 \\
& N & 30 \\
X3 & Pearson Correlation & $.550^{* *}$ \\
& Sig. (2-tailed) & .002 \\
& N & 30 \\
X4 & Pearson Correlation & $.573^{* *}$ \\
& Sig. (2-tailed) & .001 \\
& N & 30 \\
X5 & Pearson Correlation & $.563^{* *}$ \\
& Sig. (2-tailed) & .001 \\
& N & 30 \\
XTO & Pearson Correlation & 1 \\
TAL & Sig. (2-tailed) & \\
& N & 30 \\
\hline
\end{tabular}

Tabel:2

Uji Validitas Motivasi Kerja Guru

\begin{tabular}{|ll|r|}
\hline & & TOTAL \\
\hline Y1 & Pearson Correlation & $.643^{* *}$ \\
& Sig. (2-tailed) & .000 \\
& N & 30 \\
Y2 & Pearson Correlation & $.725^{* *}$ \\
& Sig. (2-tailed) & .000 \\
& N & 30 \\
Y3 & Pearson Correlation & $.772^{* *}$ \\
& Sig. (2-tailed) & .000 \\
& N & 30 \\
Y4 & Pearson Correlation & $.607^{* *}$ \\
& Sig. (2-tailed) & .000 \\
& N & 30 \\
Y5 & Pearson Correlation & $.523^{* *}$ \\
& Sig. (2-tailed) & .003 \\
& N & 30 \\
Y6 & Pearson Correlation & $.745^{* *}$ \\
& Sig. (2-tailed) & .000 \\
& N & 30 \\
Y7 & Pearson Correlation & $.585^{* *}$ \\
& Sig. (2-tailed) & .001
\end{tabular}




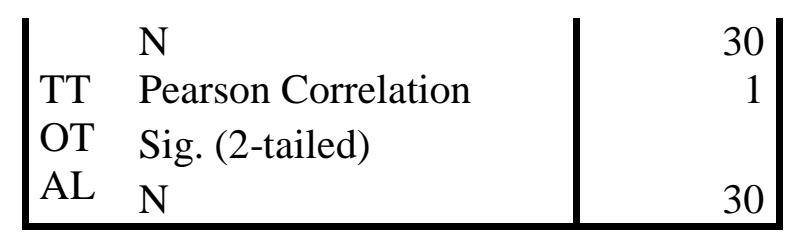

Mengacu pada table di atas dapat dikatakan bahwa butir soal yang dapat dipakai sebagai instrument penelitian adalah semua butir pertanyaan pada variable Kepemimpinan Kepala Sekolah dan Motivasi Kerja Guru adalah valid. Pertanyan-pertanyaan tersebut dianggap valid karena $r_{\text {hitung }}>r_{\text {tabel }}$ di mana $r_{\text {tabel }}=(d k=n-2,=28)$ dengan $\alpha=0,05$ adalah 0,374. Siregar (2013:79)

Adapun hasil Koefisien reliabilitas masing-masing variabel adalah sebagai berikut:

Tabel:3

Uji Realibilitas Kepemimpinan Kepala Sekolah

\begin{tabular}{|l|r|r|r|r|}
\hline & $\begin{array}{r}\text { Scal } \\
\text { e Mean } \\
\text { if Item } \\
\text { Deleted }\end{array}$ & $\begin{array}{c}\text { Scal } \\
\text { e } \\
\text { Varianc } \\
\text { e if Item } \\
\text { Deleted }\end{array}$ & $\begin{array}{c}\text { Corr } \\
\text { ected } \\
\text { Item- } \\
\text { Total } \\
\text { Correlat } \\
\text { ion }\end{array}$ & $\begin{array}{c}\text { Cro } \\
\text { nbach's } \\
\text { Alpha if } \\
\text { Item } \\
\text { Deleted }\end{array}$ \\
\hline \multirow{2}{*}{1} & 61.0 & 66.8 & .620 & .466 \\
2 & 3 & 92 & & \\
3 & 60.8 & 66.5 & .649 & .462 \\
3 & 60.8 & 68.2 & .482 & .478 \\
4 & 60.9 & 67.2 & .507 & .471 \\
3 & 81 & .5 & \\
5 & 59.7 & 50.8 & - & .906 \\
& 6 & 33 & .092 & \\
\hline
\end{tabular}

Tabel:4

Uji Realibilitas Motivasi Kerja Guru

\begin{tabular}{|c|c|c|c|c|}
\hline & $\begin{array}{c}\text { Scale } \\
\text { Mean if } \\
\text { Item } \\
\text { Deleted }\end{array}$ & $\begin{array}{c}\text { Scale } \\
\text { Varianc } \\
\text { e if Item } \\
\text { Deleted }\end{array}$ & $\begin{array}{c}\text { Correcte } \\
\text { d Item- } \\
\text { Total } \\
\text { Correlat } \\
\text { ion }\end{array}$ & $\begin{array}{c}\text { Cronbac } \\
\text { h's } \\
\text { Alpha if } \\
\text { Item } \\
\text { Deleted }\end{array}$ \\
\hline Y1 & 49.57 & 33.978 & .584 & .916 \\
Y2 & 49.67 & 33.471 & .677 & .913 \\
Y3 & 50.03 & 33.206 & .731 & .911 \\
Y4 & 49.67 & 34.713 & .552 & .917 \\
Y5 & 50.03 & 35.275 & .462 & .919 \\
Y6 & 49.80 & 32.717 & .694 & .912 \\
Y7 & 49.70 & 33.528 & .500 & .920 \\
\hline
\end{tabular}

Berdasarkan hasil output pada table di atas dapat disimpulkan bahwa intrumen penelitian semua item/butir pertanyaan pada variable Kepemimpinan Kepala Sekolah dan Motivasi Kerja Guru adalah reliable karena nilainya termasuk kategori reliabiltas yang cukup. 


\section{Hasil dan Pembahasan}

\section{Uji Asumsi}

1). Normalitas Data

Pengujian Normalitas suatu data dalam penelitian sangat penting. Hal ini dimaksudkan untuk melihat sejauh mana kenormalan suatu data tersebar. Uji normalitas tersebut dilakukan dengan menggunakan uji liliefors yang dianalisis dengan menggunakan program Statistical Product and Service Solution (SPSS) 20.0 for windows.

Adapun hasil uji normalitas dari variabel adalah sebagai berikut:

Tabel:5

Uji Normalitas Data

Tests of Normality

\begin{tabular}{|l|r|r|r|r|r|r|}
\hline & \multicolumn{3}{|c|}{ Kolmogorov-Smirnov $^{\mathrm{a}}$} & \multicolumn{3}{c|}{ Shapiro-Wilk } \\
\cline { 2 - 7 } & Statistic & \multicolumn{1}{c|}{ Df } & \multicolumn{1}{c|}{ Sig. } & Statistic & \multicolumn{1}{c|}{ df } & \multicolumn{1}{c|}{ Sig. } \\
\hline $\begin{array}{l}\text { Kepemimpinan } \\
\text { Kepala Sekolah } \\
\text { Motivasi Kerja } \\
\text { Guru }\end{array}$ & .117 & 43 & .115 & .914 & 47 & .002 \\
\hline
\end{tabular}

a. Lilliefors Significance Correction

Berdasarkan out put di atas, pada kolom Kolmogorov-Smirnov a nilai signifikansi (Sig.) adalah 0,115 untuk variable Kepemimpinan dan 0,053 dengan tarap signifikansi uji adalah $\alpha=$ 0.05 . Karena signifikansi yang diperoleh $(0,115$ dan 0,053$)>\alpha(0.05)$, maka dapat disimpulkan bahwa sampel berasal dari populasi yang berdistribusi normal. (Siregar 2013:167).

2). Homogenitas Data

Pengujian homogenitas dilakukan guna mengetahui bahwa sebaran data setiap variabel bersifat homogen. Uji homogenitas tersebut dilakukan dengan menggunakan uji levene yang dianalisis dengan menggunakan program Statistical Product and Service Solution (SPSS) 20.0 for windows.

Adapun hasil uji homogenitas adalah sebagai berikut:

Tabel:6

Hasil Uji Homogenitas Data

Test of Homogeneity of Variances

\begin{tabular}{|r|r|r|r|}
\hline $\begin{array}{c}\text { Levene } \\
\text { Statistic }\end{array}$ & df1 & df2 & \multicolumn{1}{c|}{ Sig. } \\
\hline .245 & 1 & 92 & .622 \\
\hline
\end{tabular}

Berdasarkan data di atas, ternyata diperoleh signifikansi sebesar 0,662 dengan tarap signifikansi uji adalah $\alpha=0.05$. Karena signifikansi yang diperoleh $(0,622)>\alpha(0.05)$, maka dapat disimpulkan bahwa data penelitian di atas homogen. Siregar (2013:178)

3). Linieritas Data

Tujuan dilaukannya uji linieritas adalah untuk mengetahui apakah antara variable Kepemipinan dan Reformasi Birokrasi mempunyai hubungan yang linier. Uji ini digunakan sebagai syarat dalam melaksanakan analisis penelitian dengan menggunakan regresi linier. Adapun hasil uji linieritas adalah variabel masing-masing adalah: 
Tabel:7

Hasil Uji Lineritas

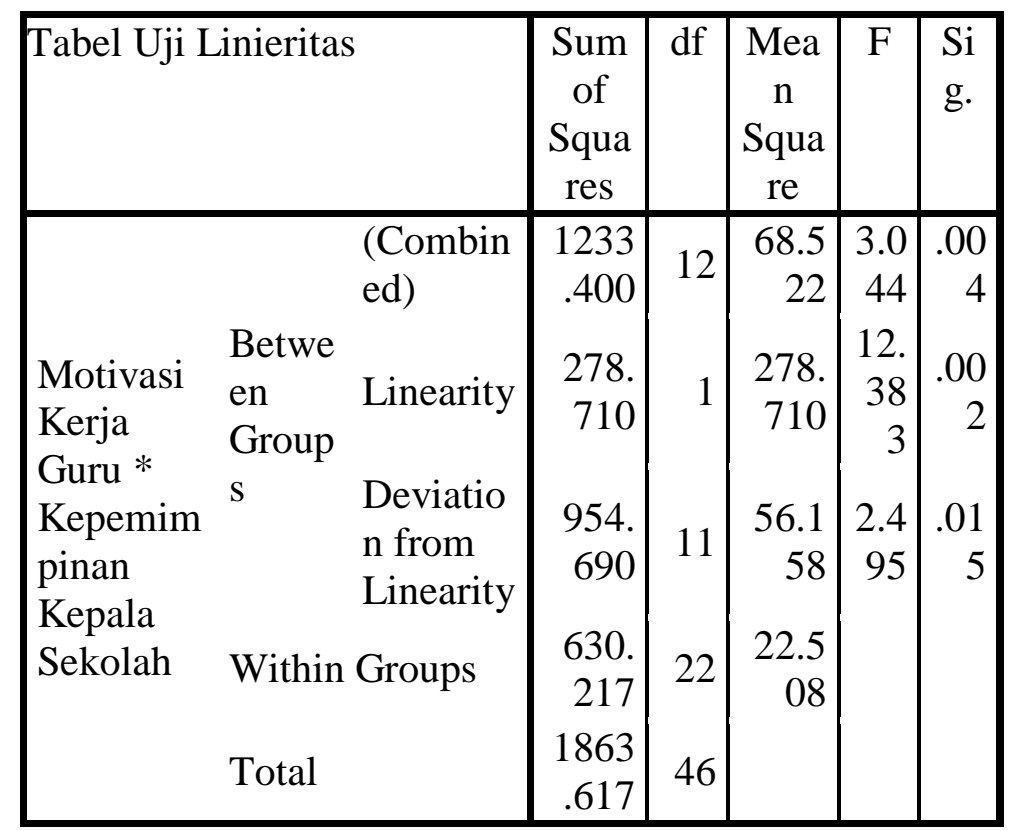

Berdasarkan table adalah: 0,002 lihat kolorn Sig. pada baris Linearity di Table Anova, Jika nilainya $<0,05$ maka bersifat linear sehingga dapat disimpulkan memenuhi syarat linearitas.

Berdasarkan table 4:8 adalah: 0,002 lihat kolorn Sig. pada baris Linearity di Table Anova, Jika nilainya $<0,05$ maka bersifat linear sehingga dapat disimpulkan memenuhi syarat linearitas.

Uji Hipotesis

Penelitian ini mengajukan 2 (dua) buah perumusan masalah, yaitu :

1. Apakah Kepemimpinan Kepala Sekolah Berpengaruh Terhadap Motivasi Kerja Guru guru SD se Kecamatan Modoinding?

2. Seberapa besar pengaruh Kepemimpinan Kepala Sekolah terhadap motivasi kerja guru-guru SD se Kecamatan Modoinding?

Perumusan pertama diuji dengan teknik analisis regresi dan korelasi sederhana, sedangkan yang kedua dilakukan dengan mengkuadratkan koefisien korelasi yang terjadi. Masing-masing pengujian tersebut akan diuraikan secara rinci di bawah ini.

1. Pengaruh Kepemipinan Kepala Sekoalah Terhadap Motivasi Kerja Guru SD se Kecamatan Modoinding

a). Uji Signifikansi dan Linieritas Persamaan Regresi

Dari hasil analisis regresi linear sederhana terhadap pasangan data Variabel Kepemimpinan Kepala Sekolah(X) terhadap variabel Motivasi Kerja Guru (Y) diperoleh koefisien arah regresi sebagai berikut:

Tabel:8

Arah Persamaan Regresi

Coefficients $^{\mathbf{a}}$ 


\begin{tabular}{|c|c|c|c|c|c|}
\hline \multirow[t]{2}{*}{ Model } & \multicolumn{2}{|c|}{$\begin{array}{l}\text { Unstandardized } \\
\text { Coefficients }\end{array}$} & \multirow{2}{*}{$\begin{array}{c}\begin{array}{c}\text { Standardiz } \\
\text { ed } \\
\text { Coefficient } \\
\text { s }\end{array} \\
\text { Beta }\end{array}$} & \multirow[t]{2}{*}{$\mathrm{t}$} & \multirow[t]{2}{*}{ Sig. } \\
\hline & B & $\begin{array}{l}\text { Std. } \\
\text { Error }\end{array}$ & & & \\
\hline (Constant) & $\begin{array}{r}37.2 \\
99\end{array}$ & 5.491 & & 6.792 & .000 \\
\hline $\begin{array}{l}\text { Kepemimpinan } \\
\text { Kepala Sekolah }\end{array}$ & .297 & .106 & .387 & 2.813 & .007 \\
\hline
\end{tabular}

a. Dependent Variable: Motivasi Kerja Guru

Berdasarkan hasil perhitungan uji signifikansi dan uji linearitas regresi di atas, dapat disimpulkan bahwa pengaruh Kepemimpinan Kepala Sekolah(X) terhadap variabel Motivasi Kerja Guru (Y) signifikan dan linier. Hal ini dibuktikan karena $F_{\text {hitung }} 7.913>\alpha(0,05)$

Selanjutnya, persamaan regresi $\hat{Y}=37.299+0.297 X$ menunjukan bahwa setiap kenaikan satu skor Kepemimpinan Kepala Sekolah akan menyebabkan kenaikan skor Motivasi Kerja Guru sebesar 0,297 pada konstanta 37.299.

b). Uji Signifikansi Korelasi

Analisis korelasi digunakan untuk mengetahui ada atau tidak hubungan anatara dua variable dan juga untuk mengetahui seberapa erat hubungan antara variable Kepemimpinan Kepala Sekolah (X) dan variable Motivasi Kerja Guru (Y).

Adapu hasil perhitungnnya adalah:

Tabel:9

Korelasi Variabel Kepemimpinan Kepala Sekolah dengan Motivasi Kerja Guru Correlations

\begin{tabular}{|ll|r|r|}
\hline & & $\begin{array}{r}\text { Kepemi } \\
\text { mpinan }\end{array}$ & $\begin{array}{r}\text { Reforma } \\
\text { si } \\
\text { Birokras } \\
\text { i }\end{array}$ \\
\hline Kepemimpi & $\begin{array}{l}\text { Pearson } \\
\text { Correlation } \\
\text { nan Kepala }\end{array}$ & 1 & $.387^{* *}$ \\
Sekolah & Sig. (2- & & \\
& tailed) & & .007 \\
& $\begin{array}{l}\text { Nearson } \\
\text { Correlation }\end{array}$ & $.387^{* *}$ & 47 \\
Motivasi & $\begin{array}{l}\text { Sig. (2- } \\
\text { tailed) }\end{array}$ & .007 & \\
Kerja Guru & N & 47 & 47 \\
\hline
\end{tabular}

**. Correlation is significant at the 0.01 level

(2-tailed).

Berdasarkan tabel di atas diketahui bahwa koefisien korelasi $r\left(r_{y x}\right)$ sebesar 0.387. Artinya korelasi Kepemimpinan Kepala Sekolah terhadap Motivasi Kerja Guru tergolong rendah Selanjutnya untuk mengetahui signifikansi koefisien korelasi $r$ yang telah diperoleh, dilakukan uji signifikansi koefisien korelasi dengan uji $t$, seperti dalam tabel di bawah ini

Tabel:10

Uji Signifikansi Korelasi

Coefficients $^{\mathbf{a}}$

50| Jurnal Civic Educatioan: Media Kajian Pancasila dan Kewarganegaraan 


\begin{tabular}{|l|c|c|c|}
\hline & Model & $\mathrm{t}$ & Sig. \\
\hline 1 & $\begin{array}{c}\text { Kepemimpina } \\
\text { n Kepala } \\
\text { sekolah }\end{array}$ & 2.813 & .007 \\
\hline
\end{tabular}

a. Dependent Variable: Motivasi Kerja Guru

Dari hasil uji $t$ di atas diperoleh perbandingan nilai $t_{\text {hitung }} 6.792>t_{\text {tabel }}(\alpha 0.05) 1.671$. Dengan demikian $H_{0}$ ditolak dan $H_{1}$ diterima. Artinya koefisien korelasi $r_{y x}$ signifikan. Jadi dapat disimpulkan bahwa terdapat pengaruh yang signifikan antara Kepemimpinan Kepala Sekolah (X) terhadap Motivasi Kerja Guru (Y).

\section{Besar Pengaruh Kepemimpinan Kepala Sekolah terhadap Motivasi Kerja Guru SD se Kecamatan Modoinding}

Besar Pengaruh Kepemimpinan Kepala Sekolah terhadap Motivasi Kerja Guru se Kecamatan Modoinding dapat diketahu dengan mengkuadratkan hasil korelasi yang terjadi seperti yang ditunjukan table 11 di bawah ini:

Tabel 11

Koefisien Determinasi

Model Summary ${ }^{b}$

\begin{tabular}{|c|c|c|c|c|}
\hline $\begin{array}{c}\text { Mo } \\
\text { del }\end{array}$ & $\mathrm{R}$ & $\begin{array}{c}\mathrm{R} \\
\text { Squar } \\
\mathrm{e}\end{array}$ & $\begin{array}{c}\text { Adjusted } \\
\mathrm{R} \text { Square }\end{array}$ & $\begin{array}{c}\text { Std. } \\
\text { Error of } \\
\text { the } \\
\text { Estimate }\end{array}$ \\
\hline 1 & $.387^{\mathrm{a}}$ & .150 & .131 & 5.935 \\
\hline
\end{tabular}

a. Predictors: (Constant), Kepemimpinan

Kepala Sekolah

b. Motivasi Kerja Guru

Berdasarkan table di atas diketahui bahwa besar Kepemimpinan Kepala Sekolah terhadap Motivasi Kerja Guru se Kecamatan Modoinding dapat adalah 0,150 atau 15 persen. Hal ini meneujukan bahwa 15 \% Kepemimpinan Kepala Sekolah menentukan Motivasi Kerja Guru se Kecamatan Modoinding. Sedangkan 85 persen dipengaruhi oleh faktor lain yang tidak diteliti

Motivasi Kerja guru adalah suatu keinginan untuk melaksanakan tanggungjawabnya. Guru yang memiliki motivasi tinggi dalam pekerjaannya akan akan senantiasa bekerja keras untuk mengatasi segala jenis permasalahan yang dihadapi dalam proses kegiatan pembelajaran dengan harapan mencapai hasil yang lebih baik.

Menurut Mangkunegara dalam Mirna Herawati dkk (2019:106) menjelaskan bahwa motivasi merupakan dorongan yang timbul pada diri seseorang yang menggerakannya untuk melakukan sesuatu.

Hal yang sama dikemukakan oleh Uno (Mirna Herawati dkk 2019:106) bahwa motivasi kerja merupakan salah satu faktor yang turut akan menentukan kinerja atau hasil kerja seseorang. Dalam bidang pendidikan motivasi kerja guru tidak lain adalah suatu proses yang dilakukan untuk menggerakkan guru agar perilaku mereka dapat diarahkan pada upaya-upaya nyata untuk mencapai tujuan yang telah ditetapkan) Dari uraian tersebut dan dengan merujuk pengertian motivasi, maka dalam penelitian ini yang dimaksud dengan motivasi kerja guru 
adalah dorongan yang ada di dalam diri seseorang guru untuk melakukan berbagai aktivitas guna mencapai suatu tujuan tertentu yang telah ditetapkan.

Namun demikian motivasi kerja guru SD se Kecamatan Modoinding di masa pandemi Covid19 berdasarkan hasil penelitian hanya sekitar 15 persen dipengarhi oleh kepemimpinan Kepala sekolah. Dengan demikian dapat dikatakan bahwa motivasi kerja guru memberi jawaban bahwa apa yang kepala sekolah lakukan saat ini agar guru-guru termotivasi untuk melakukan pekerjaannya dalam melaksakan pengajaran tidaklah dilakukan oleh kepala sekolah. Memahami apaya yang disampaikan oleh Syamsul Kepemimpinan kepala sekolah merupakan suatu kemampuan dan kesiapan kepala sekolah untuk mempengaruhi, membimbing, mengarahkan, dan menggerakkan staf sekolah agar dapat bekerja secara efektif dalam rangka mencapai tujuan pendidikan dan pengajaran yang telah ditetapkan, atau bisa dikatakan bantuan yang diberikan oleh kepala sekolah terhadap penetapan pencapaian tujuan pendidikan (Syamsul 2017:276).

Berdasarkan data hasil penelitian Motivasi Kerja sguru SD se Kecamatan Modoinding memiliki motivasi yang sangat baik. Hal ini dapat dilihat dengan jumlah skor yang diperoleh dari jawaban responden sebesar 1003 dari 1505 skor maksimal apabila responden memilih skor tertinggi untuk setiap butir pertanyaan, atau dengan motivasi kerja guru sudah berjalan $66,65 \%$. Hal ini menunjuan bahwa dalam melaksnakan tugasnya di masa pandemi dapat dikatakan sedang.

Dari data tersebut maka Kepemimpinan kepala Sekolah SD se Kecamatan Modoinding belum berperan penting dalam meningkatkan motivasi kerja guru. Jika mengacu pada hasil perhitungan uji signifikansi dan uji linearitas regresi di atas, dapat disimpulkan bahwa pengaruh Kepemimpinan Kepala Sekolah(X) terhadap variabel Motivasi Kerja Guru (Y) signifikan dan linier.

Artinya bahwa penting bagi Kepala Sekolah untuk melaksnakan perannya di masa pendemi Covid19 sebagai manajer untuk dapat mengatur pekerjaan guru dengan melakukan pengendalian dan pengawasan atas pelaksanaan pembelajaran di rumah yang telah ditugaskan kepada guru mengingat indikator ini terbilang rendah dilakukan oleh kepala sekolah dengan persentasennya hanya menyacapai 105 dari 215 nilai maksimal atau tugas ini hanya mencapai sebesar 46.7\%. Padahal Menurut Purwanto dalam Khairuddin (2020:176), bahwa seorang kepala sekolah mempunyai sepuluh macam peranan, yaitu : "Sebagai pelaksana, perencana, seorang ahli, mengawasi hubungan antara anggota-anggota, mewakili kelompok, bertindak sebagai pemberi ganjaran, bertindak sebagai wasit, pemegang tanggung jawab, sebagai seorang pencipta, dan sebagai seorang ayah.

Berdasarkan hasil olahan data analisis regresi maka dapat disimpulkan bahwa semakin baik pelaksanaan kepemimpinan kepala sekolah se SD Kecamatan Modoinding akan menaikan pula motivasi kerja guru dalam mengajar. Artinya 66,65\% motivasi kerja guru hany $15 \%$ merupak hasil dari kepimpina kepal sekolah motivasi keja guru yang ada saat ini dan nilai kepemimpian kepala sekolah dalam menggerakan organisasi sekolah agar tetap maksimal dalm melaksnakan perannya dengan tetap melaksnakan protocol kesehatan adalah 723 dari 1125 ada hanay 68,9\%.

\section{Kesimpulan}

Berdasarkan pembahasan di atas dapat disimpulkan bahwa Motivasi kerja guru-guru se Kecamatan Modoinding yang sedang tersebut hanya 15\% datang dari pihak kepala sekolah mereka. Namun demikian bahwa kepala sekolah memiliki peran yang penting dalam mendorong motivasi guru dalam melaksanakan tugas mereka untuk mengajar.

Semakin Kepala sekolah se Kecamatan Modoinding melaksanakan fungsinya secara maksimal sebagai manejer sekolah di masa pandemic Covid19, maka akan meningkatkan motivasi kerja guru, dimana kenaikannya bersifat linier.

Kepala sekolah perlu meningkatkan perenya senagai kepala sekolah terutama dalam melakukan pengendalian dan pengawasan atas pelaksanaan pembelajaran di rumah yang

52| Jurnal Civic Educatioan: Media Kajian Pancasila dan Kewarganegaraan 
telah ditugaskan kepada guru. Di sisi lai guru harus mengembangkan potensi dan kemampuan dalam mengajar terutama penguasaan teknologi komunikasi sebagai sara penting dalam pembelajaran daring.

Guru juga harus membangun motivasi diri untuk mengajar secara produkti di masa pendemi mengingat nilai motivasinya $66,65 \%$ atau tidak dalam nilai yang maksimal.

\section{Referensi}

Achmad Fadhil dan Yuniadi Mayowan.2018. Jurnal Administrasi Bisnis (JAB)|Vol. 54 No. 1 Januari 2018|administrasibisnis.studentjournal.ub.ac.id

Astrid Setianing Hartanti dan Tjutju Yuniarsih 2018. Pengaruh kompetensi profesional guru dan motivasi kerja terhadap kinerja guru di sekolah menengah kejuruan. Jurnal Pendidikan manajemen Perkantoran

Cndi Grace dkk. Kinerja Guru sekolah dasar di Masa Pandemi Covid19 (Studi di SD Inpres Tateli Kecamatan Mandolang Kabupaten Minahasa)

Ekhwanudin, 2021. https://radarsemarang.jawapos.com/rubrik/untukmuguruku/2021/01/04/kepemimpinan-kepala-sekolah-di-tengah-pandemi-covid-19/

Herawati Syamsul Jurnal Idaarah VOL. I, NO. 2, Desember 20072017

Husein Umar. 2013. Metode Penelitian untuk Skripsi dan Tesis. Jakarta: Rajawali

Khairuddin Jurnal Pendidikan "EDUKASI” ISSN : 2087-0310 E-ISSN : 2721-7728Vol.8, No.2, 2020

Mirna Herawati dkk, 2019.Motivasi Kerja Guru dan Pengarunya pada Kinerja Guru di Yayasan Al Islam Al Ma'ruf. Research and Development Journal Of Education Vol. 5 No. 2 April 2019

Riduwan, 2007. Pengantar Statistik Sosial. Bandung: ALFABETA.

Siregar, Syofian, 2012. Statistik Parametik untuk Penelitian Kuantitatif. Bumi Aksara Jakarta Slamet Riyadi, Aria Mulyapradana, 2017. Pengaruh Motivasi Kerja terhadap Kinerja Guru Radafthul Aftal di Pekalongan. Jurnal Litbang Kota Pekalongan.

Sugiyono, 2010, Metode Penelitian Kualitatif, Kuantitatif, R \& D. Bandung: ALFABETA 